\title{
Hepatitis B and C Immunological and Molecular Parameter Analysis in HIV-Positive Patients Undergoing Antiretroviral Therapy at Saint Camille Hospital in Ouagadougou (HOSCO), Burkina Faso
}

\author{
Denise P. Ilboudo ${ }^{1,2,3,4^{*}}{ }^{\circledR}$, W. W. Eudoxie Kévine Savadogo5, Théodora M. Zohoncon4,5,6 ${ }^{1}$, \\ Estelle Savadogo ${ }^{6}$, Yéri Esther Hien'3, Lassina Traore',4, Djéneba Ouermi1,4, \\ Wendkuuni Florencia Djigma ${ }^{1,4}$, Christelle M. Nadembega ${ }^{1,4}$, Marius Belemgnegre ${ }^{6}$, \\ Paul Ouedraogo ${ }^{6}$, Mahamoudou Sanou$^{7}$, Damintoti Simplice Karou ${ }^{8}$, \\ Yves Traore $^{3}$, Jacques Simpore ${ }^{1,4,5,6}$ (1)
}

${ }^{1}$ Laboratory of Molecular Biology and Molecular Genetics (LABIOGENE) UFR/SVT, University Joseph KI-ZERBO, Ouagadougou, Burkina Faso

${ }^{2}$ University of Fada N'Gourma, Fada N'Gourma, Burkina Faso

${ }^{3}$ Laboratory of Biochemistry and Applied Immunology, University Joseph KI-ZERBO, Ouagadougou, Burkina Faso ${ }^{4}$ Biomolecular Research Center Pietro Annigoni (CERBA), Ouagadougou, Burkina Faso

${ }^{5}$ Université Saint Thomas d'Aquin, Faculté de Médecine, Ouagadougou, Burkina Faso

${ }^{6}$ Hopital Saint Camille Ouagadougou (HOSCO), Ouagadougou, Burkina

${ }^{7}$ Unité de Formation et de Recherche en Science De la Santé (UFR/SDS), Université Joseph KI-ZERBO (UJKZ), Ouagadougou, Burkina Faso

${ }^{8}$ Ecole Supérieure des Techniques Biologiques et Alimentaires (ESTBA-UL), Université de Lomé, Lomé, Togo

Email: *denise.ilboudo@gmail.com

How to cite this paper: Ilboudo, D.P., Savadogo, W.W.E.K., Zohoncon, T.M., Savadogo, E., Hien, Y.E., Traore, L., Ouermi, D., Djigma, W.F., Nadembega, C.M., Belemgnegre, M., Ouedraogo, P., Sanou, M., Karou, D.S., Traore, Y. and Simpore, J. (2022) Hepatitis B and C Immunological and Molecular Parameter Analysis in HIV-Positive Patients Undergoing Antiretroviral Therapy at Saint Camille Hospital in Ouagadougou (HOSCO), Burkina Faso. Advances in Infectious Diseases, 12, 20-41. https://doi.org/10.4236/aid.2022.121002

Received: November 10, 2021

Accepted: January 24, 2022

Published: January 27, 2022

\begin{abstract}
Knowledge of the clinical and biological profile of patients infected with HIV and hepatitis B and/or C is essential in order to identify and implement effective management strategies. Methods. This was a retrospective descriptive study from January 01, 2016 to June 01, 2021. Adult patients aged at least 18 years infected with HIV type 1 and/or 2, naïve to ARV treatment. Univariate analyses were assessed using Pearson's Chi2 test. The Student Newman test was used for comparison between groups using R software version 4.0.2. $\mathbf{O b}$ jective: To draw up the epidemiological, clinical, paraclinical and evolutionary profiles of HIV-treated-patients in relation to HIV/HBV and HIV/HCV co-infections in order to allow the identification and the implementation of effective management strategies. Results. Of the 379 patients included 280
\end{abstract}


Copyright $\odot 2022$ by author(s) and Scientific Research Publishing Inc. This work is licensed under the Creative Commons Attribution International License (CC BY 4.0).

http://creativecommons.org/licenses/by/4.0/
(73.88\%) were women. At treatment initiation, the mean age was $40.14 \pm$ 11.84 years. The majority of patients consulted at WHO stage III (51.45\%). Clinical suspicion was the most frequent screening circumstance (51.71\%). The pathologies frequently reported at the first consultation were diarrhea $(28 \%)$ and shingles (16\%). Body mass index was normal in $50.5 \%$ of patients. HIV1 infection was the majority (91.03\%). A total of 270 had a CD4 count at treatment initiation. The mean CD4 cell count was $304.17 \pm 242.06$ cells $/ \mu \mathrm{L}$, and $116(42.59 \%)$ of them had a CD4 $\leq 200$ cells/ $\mu \mathrm{L}$. Viral load at treatment initiation was documented in 62 patients $(16.35 \%)$ and $70.97 \%$ of them had a detectable viral load (greater than 1000 copies/mL). The clinical and biological evolution was relatively good in patients after therapeutic initiation. HIV-HBV co-infection was $24.11 \%$ and HIV-HCV co-infection was $2.26 \%$. The mortality rate was $3.69 \%$. Conclusion: These results reflect a significant delay in HIV infection diagnosis. Furthermore, hepatitis B and/or C is co-infections that increasingly affect people living with HIV. It also appears that COVID 19 disease has had a strong impact on patient management. Thus, new screening strategies must be implemented to encourage early diagnosis of HIV, hepatitis B and C. Effective strategies are also necessary to fight HIV in the context of epidemics and/or pandemics.

\section{Keywords}

HIV, Clinical-Biological Profile, Hepatitis B and C, Co-Infection, Burkina Faso

\section{Introduction}

Human immunodeficiency Virus (HIV), Hepatitis B virus (HBV), and Hepatitis $\mathrm{C}$ virus (HCV), are the three most common chronic viral infections all over the world. They share similar transmission routes including sexual, blood-blood contact, and injecting drug usage [1]. Co-infection with HIV and HCV and/or $\mathrm{HBV}$ is very common in certain populations, such as intravenous drug users (IDUs) who often share the contaminated needles/syringes for intravenous drug injection. The rates of HIV-HBV co-infection are reported as high as $10 \%-20 \%$ in countries where $\mathrm{HBV}$ infection is either endemic or intermediate to high HBV cases. It has been observed that HBV/HIV co infection leads to increased morbidity and mortality as compared to HIV or HBV mono-infections [2]. The ever increasing burden of these infections has become a growing concern [3]. With increased access to antiretroviral drugs for HIV patients, migrating populations and social networking by intravenous drug use, cases of HBV and HCV co infections have been on the rise [4]. Studies show that HIV co infection adversely impacts on the natural history of HBV and HCV [4] by accelerating progression to chronic liver disease due to drug-related hepatotoxicity and hepatitis reactivation [5] [6]. At this stage, most patients are likely to die due to liv- 
er-related diseases compared to those without HIV infection [7]. Viral hepatitis is a global health challenge worldwide, particularly in low and middle-income countries [8]. In Africa, hepatitis B virus (HBV) is estimated to affect around 75 million people including 1.9 million in Burkina Faso [9]. The prevalence of $\mathrm{HBV}$ and HCV was still high in African countries: in fact, $12.2 \% \mathrm{HBV}$ prevalence in Nigeria [10]; an overall prevalence of HBsAg of $30.9 \%$ in Cote d'Ivoire [11]; and $12.4 \%$ in Burkina Faso [12] versus 9.1\% [13]. In Senegal prevalence of HBsAg in the general population was $8.1 \%$ in 2016 [14]. HCV prevalence is estimated to 2.8\% in Kenya, 3.2\% in Ghana, $4.9 \%$ in Cameroon and, finally, $6.1 \%$ in Burkina Faso [15]. The rate of co-infection between HCV and HIV was also high [16].

In short, hepatitis $\mathrm{B}$ and $\mathrm{C}$ viruses and HIV constitute major problems in the Burkinabé health system [17]. The prevalence of HIV infection in the adult population of Burkina Faso is estimated at $0.70 \%$ in 2019 against $0.9 \%$ in 2014 and $1 \%$ in 2012, with a large predominance of HIV 1 [18]. In practice, studies highlight the impact of these viral infections on the capacity of transfusion blood in the country, HIV 1 is $1 \%$ and hepatitis C is $5 \%$. So, viral hepatitis infection is the most common in the country, but it is silent and shows no signs. This implies a particular danger in a country where the prevalence of HIV AIDS is not negligible, these viruses sharing the same routes of contamination as HIV. Faced with the alarming situation caused by these hepatitis viruses in Burkina Faso, the general objective of the present study was to determine the seroprevalences of antibodies against hepatitis $\mathrm{B}$ and $\mathrm{C}$ viruses and to analyze the impact of the immunological and molecular parameters of these viral hepatitis in HIV-positive patients under antiretroviral treatment (ART), at the Saint Camille Hospital in Ouagadougou (HOSCO), Burkina Faso.

\section{Methodology}

\subsection{Framework of the Study}

The study was conducted in the city of Ouagadougou, the political capital of Burkina Faso, and at the Prevention of Mother-to-Child Transmission (PMTCT) unit of the Saint Camille Hospital in Ouagadougou.

\subsection{Type and Period of Study}

This is a descriptive and analytical cross-sectional study with retrospective data collection. It covered the period from $01^{\text {st }}$ January 2016 to $01^{\text {st }}$ June 2021. During the study period, 504 patients started antiretroviral treatment in the active file of which 379 patients met the inclusion criteria.

\subsection{Study Population}

A total of 379 patients, whose clinical records were available for the study period were included. Inclusion criteria were HIV1 and/or HIV2 infection and follow-up in the active file of the PMTCT service. Patients transferred to the Day 
Hospital, under antiretroviral treatment were excluded from the study.

\subsection{Data Collection Survey}

For data collection, a collection form was developed. This data collection consisted of a review of the clinical files of PLHIV who are followed up at the HOSCO and the recording of parameters of interest. We sorted the files concerned for our study and filled out the data collection forms.

\subsection{Statistical Analysis of Data}

Data were entered into Excel 2016 and then analyzed using R software version 4.0.2. Prevalences were calculated with $95 \%$ confidence intervals (95\% CI). Differences between prevalences, different age groups and CD4 counts, were assessed using Pearson's Chi2 test. The Student Newman test was used for comparison between groups with $\mathrm{R}$ software version 4.0.2. Results with $\mathrm{p}<0.05$ were considered statistically significant.

\subsection{Ethical Considerations}

This study was conducted in the context of routine care. All information collected was kept strictly confidential and patient names were not included in the exported data. The study had the approval of the institutional ethics committee of the HOSCO.

\section{Results}

\subsection{Socio-Demographic Characteristics}

The majority of patients were female, with 280 women (73.88\%), giving a male/female sex ratio of 0.35 . The mean age was $40.14 \pm 11.84$ years with extremes of 18 and 81 years. The most represented age group was $35-44$ years with a frequency of $31.66 \%$. The distribution of patients according to their socio-professional activity revealed a high proportion of unemployed (31.66\%) and among these, housewives were the most represented (25.65\%). There were $22.96 \%$ of traders, $8.71 \%$ of students, $4.49 \%$ of farmers and $1.85 \%$ of civil servants. According to the area of residence, patients living in urban areas were the most represented in the study population (96.04\%) and the majority of them, $93.93 \%$, came from the city of Ouagadougou, compared to $3.43 \%$ from rural areas. The area of origin was not specified for two (02) patients (0.52\%). Patients in couples represented $56.21 \%$ of the study population with a predominance of monogamous married patients (38.79\%) and 7.92 of polygamous patients. Single patients were $27.7 \%$, widowed $11.87 \%$, cohabiting $9.7 \%$ and divorced $4.22 \%$. The level of education was specified for 361 patients, i.e. $95.25 \%$ of the patients included. The majority of patients (35.09\%) had no schooling and only $11.35 \%$ of patients had attained higher education, 29.29 secondary education and 19.53 primary education. These results on the level of education specify a statistically significant difference with the value of $\mathrm{p}<0.001$. A large proportion $(32 \%)$ of the 
patients included in the study had informed their sexual partner about their serological status. This parameter was not applicable in the majority (30\%) (Table 1).

\subsection{Patients' Clinical and Biological Characteristics at Initiation and Under Antiretroviral Treatment}

\subsubsection{Evolution of Clinical Characteristics}

1) Non-HIV history

Table 1. Socio-demographic characteristics of the study population.

\begin{tabular}{|c|c|c|}
\hline & Effective & Percentage \\
\hline \multicolumn{3}{|l|}{ Sexe } \\
\hline Female & 280 & $73.88 \%$ \\
\hline Male & 99 & $26.12 \%$ \\
\hline \multicolumn{3}{|l|}{ Socio-professional activity } \\
\hline Unemployed & 120 & $31.66 \%$ \\
\hline Students & 33 & $8.71 \%$ \\
\hline Farmers & 17 & $4.49 \%$ \\
\hline Civil servants & 7 & $1.85 \%$ \\
\hline Traders & 87 & $22.96 \%$ \\
\hline Retirees & 3 & $0.79 \%$ \\
\hline \multicolumn{3}{|l|}{ Area of residence } \\
\hline Urban areas & 364 & $96.04 \%$ \\
\hline Rural areas & 13 & $3.43 \%$ \\
\hline \multicolumn{3}{|l|}{ Marital status } \\
\hline Monogamous married & 147 & $38.79 \%$ \\
\hline Polygamous married & 30 & $7.92 \%$ \\
\hline Singles & 105 & $27.7 \%$ \\
\hline Widowed & 44 & $11.87 \%$ \\
\hline Cohabiting & 37 & $9.7 \%$ \\
\hline Divorced & 16 & $4.22 \%$ \\
\hline \multicolumn{3}{|l|}{ Level of education } \\
\hline No schooling & 133 & $35.09 \%$ \\
\hline Higher education & 43 & $11.35 \%$ \\
\hline Secondary education & 111 & $29.29 \%$ \\
\hline Primary education & 74 & $19.53 \%$ \\
\hline \multicolumn{3}{|l|}{ Information to the sexual partner } \\
\hline Sexual partner informed & 123 & $32 \%$ \\
\hline Sexual partner not informed & 112 & $30 \%$ \\
\hline Not applicable & 144 & $38 \%$ \\
\hline
\end{tabular}


Non-HIV related history was diabetes and hypertension. Hypertension was a history in 9 patients of whom 8 were on treatment. Also, 3 patients or $0.79 \%$ had diabetes and 2 of them were on treatment. The association of hypertension and diabetes was recorded in 1 patient. There was no statistically significant difference ( $p$-value $>0.05$ ) between the initiation of antihypertensive treatment and the initiation of antidiabetic treatment (Table 2).

\section{2) Circumstances of screening}

Table 3 provides information on the screening circumstances of the patients in the study. Clinical suspicion was the most frequent screening circumstance with $51.71 \%$ of cases ( $\mathrm{p}$-value $<2.2 \mathrm{e}-16$ ).

3) WHO stage

WHO clinical stage III was higher ( $\mathrm{p}$-value $<2.2 \mathrm{e}-16)$ than the other stages and accounted for $51.45 \%$ of the cases, followed by clinical stage I (33.77\%). This

Table 2. Frequency of patients according to their history.

\begin{tabular}{ccccc}
\hline \multicolumn{5}{c}{ Incidence of past service history (\%) } \\
\hline HTA & Diabetes & HTA/Diabetes & P-value \\
\hline Diseased patient & $9 / 379(2.37 \%)$ & $3 / 379(0.79 \%)$ & $1 / 379(0.26 \%)$ & 0.01951 \\
Under treatment & $8 / 9(88.89 \%)$ & $2 / 3(66.67 \%)$ & $1 / 1(100 \%)$ & 0.9547 \\
\hline
\end{tabular}

$\mathrm{p}<0.05$.

Table 3. Distribution of patients according to the circumstance of discovery of their status, WHO clinical stages and BMI at initiation.

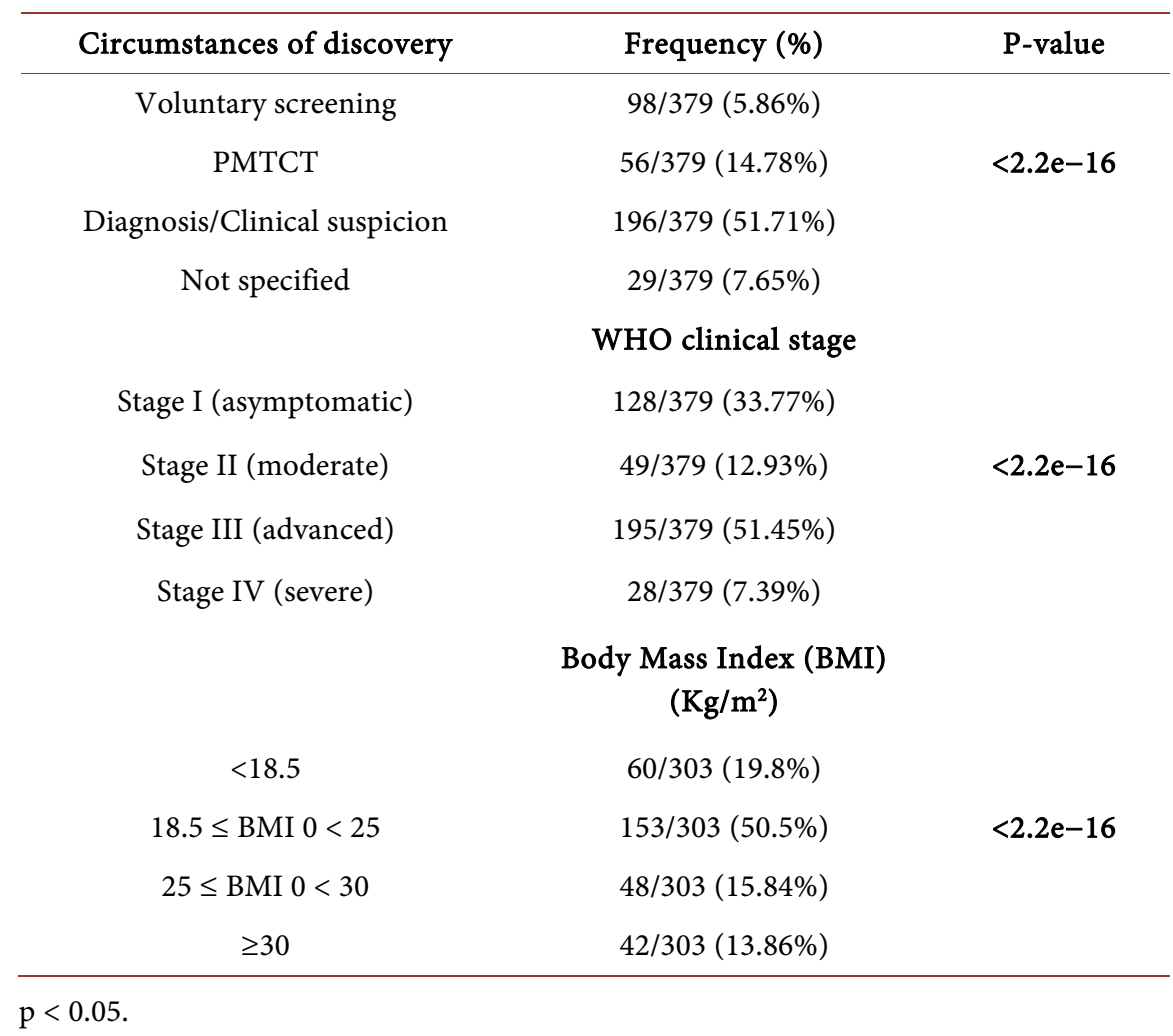


difference between clinical stages was also statistically significant. Table 3 shows also the distribution of patients according to their WHO clinical stage at inclusion.

4) Body mass index (BMI) evolution

BMI was assessed in 303 patients or $79.95 \%$ of the population. Before treatment, the mean BMI was $23.14 \pm 5.7 \mathrm{~kg} / \mathrm{m}^{2}$ and slightly more than half of the patients or $50.5 \%$ had a normal BMI with a significance of results $\mathrm{p}<2.2 \mathrm{e}-16$ (Table 3 ). Compared to data after the treatment, we observed a progressive weight gain of the patients after they started ART (Figure 1).

5) Evolution of clinical events

The clinical events at ARV treatment initiation were reported in 102 patients or $26.91 \%$ of the study population. These clinical events after ART initiation were dominated by diarrhea and herpes zoster with $28 \%$ and $16 \%$ respectively. These differences were statistically significant at $\mathrm{p}=2.56 \mathrm{e}-08$ (Table 4 ). They changed under treatment. In fact, the number of clinical events decreased during follow-up. Indeed, of the 102 patients presenting a clinical event at the beginning of treatment, only 38 (10.03\% of the study population) presented a clinical failure during treatment.

\subsubsection{Evolution of Biological Data}

1) Type of $H I V$

HIV 1 infection was the majority in the study population and concerned 345 patients or $91.03 \%(345 / 379)$ and HIV 2 was $4.22 \%(16 / 379)$. Co-infection between HIV1 and 2 was $4.75 \%$ (18/379). The differences between results were highly significant $\mathrm{p} \leq 2.2 \mathrm{e}-16$.

Table 4. Distribution of clinical events in patients after initiation.

\begin{tabular}{ccc}
\hline Clinical event & Frequency (\%) & p-value \\
\hline Diarrhea & $28 / 100(28 \%)$ & \\
Tuberculosis & $7 / 100(7 \%)$ & \\
Prurigo & $8 / 100(8 \%)$ & \\
Zona & $16 / 100(16 \%)$ & $2.56 e-08$ \\
Weight loss & $8 / 100(8 \%)$ \\
Herpes & $2 / 100(2 \%)$ \\
Mycosis & $6 / 100(6 \%)$ \\
Pneumocystis & $2 / 100(2 \%)$ \\
Community-acquired pneumonia & $4 / 100(4 \%)$ \\
Dermatosis & $6 / 100(6 \%)$ \\
Others & $9 / 100(9 \%)$ \\
Total & $4 / 100(4 \%)$ & \\
& $100 / 100(100 \%)$ &
\end{tabular}

$\mathrm{p}<0.05$. 


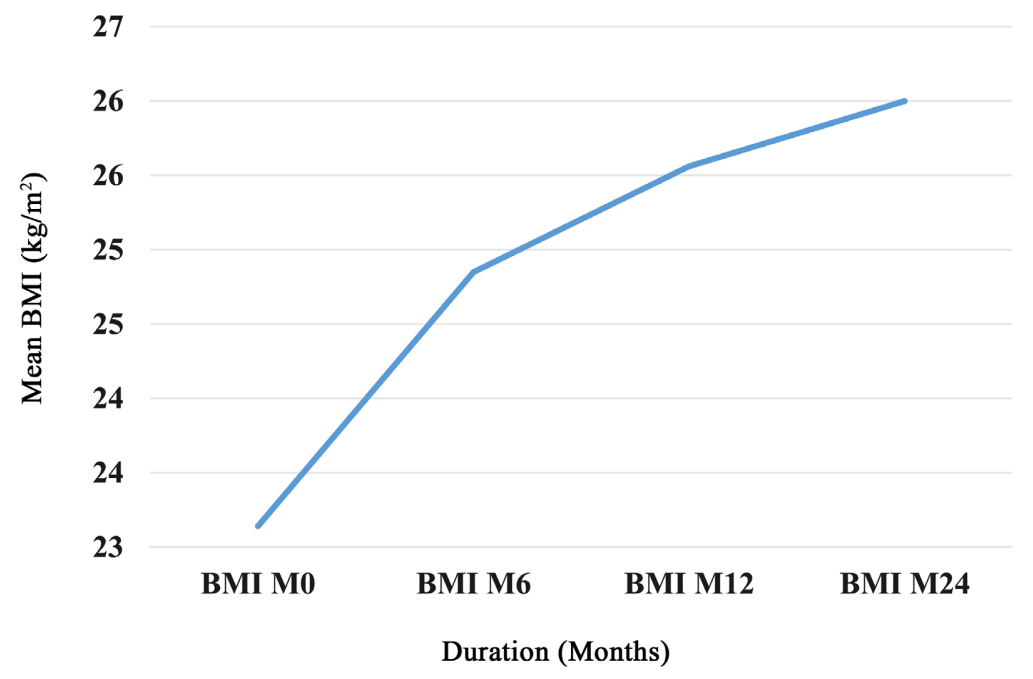

Figure 1. BMI changes after ART initiation. Legend: BMI = body mass index; M0 = month 0, M6 = 6 months, M12 = 12 months, M24 = 24 months.

\section{2) CD4 evolution after initiation of $A R V$ treatment}

The initial CD4 quantification was performed for 270 patients. We found $71.24 \%$ of the study population at treatment initiation with a mean CD4 count of $304.17 \pm 242.06$ cells $/ \mu \mathrm{L}$, the extremes ranging from 1 to $1286 \mathrm{cells} / \mu \mathrm{L}$. The majority of patients (42.59\%) had CD4 counts below 200 cells/ $\mu \mathrm{L}$. They gained under treatment. Figure 2 shows the evolution of patients' CD4 lymphocytes according to the duration of treatment. The gain in CD4 was regular in patients after initiation of treatment. The plateau was reached rapidly with stabilization after 12 months of treatment and return to near normal CD4 values. Under treatment, $12.14 \%$ of patients experienced immunological failure.

3) Evolution of the viral load after initiation of ARV treatment

The viral load at initiation of therapy was documented in only 62 patients or $16.35 \%$ of patients and $70.97 \%$ had a detectable viral load (greater than 1000). The differences observed between the viral load groups are statistically significant with $p=0.0103$. Notable changes have been noted after treatment and during treatments. Indeed, a large majority of patients $(91.25 \%)$ who started treatment had an undetectable viral load after 6 months of follow-up compared to $82.76 \%$ after 12 months. Virological failure was reported in $11.08 \%$ of patients on ARV treatment. The data are shown in Figure 3.

\section{4) Biochemical parameters}

Alanine aminotransferase (ALT) value was recorded in 300 (68.60\%) patients. The median was 21 . UI/ 1 with extremes of 0 and 355.7 and the mean was $28.58 \pm$ $28.83 \mathrm{UI} / \mathrm{l}$. Values were normal in $97.09 \%$ of patients. The mean of aspartate aminotransferase (ASAT) was $34.83 \pm 28.05 \mathrm{UI} / 1$ with extremes of 6.2 and 350.2 UI/l. Blood glucose values were not informed in $40.63 \%$ of our patients. The mean was $5.06 \pm 2.24 \mathrm{IU} \mathrm{mmol} / \mathrm{L}$; and most of our patients, $95.45 \%$ had normal blood glucose levels. The mean hemoglobin level at therapeutic initiation was $11.62 \pm 1.99 \mathrm{~g} / \mathrm{dL}$ with extremes ranging from 6 to $17.7 \mathrm{~g} / \mathrm{dl}$ and a median of 


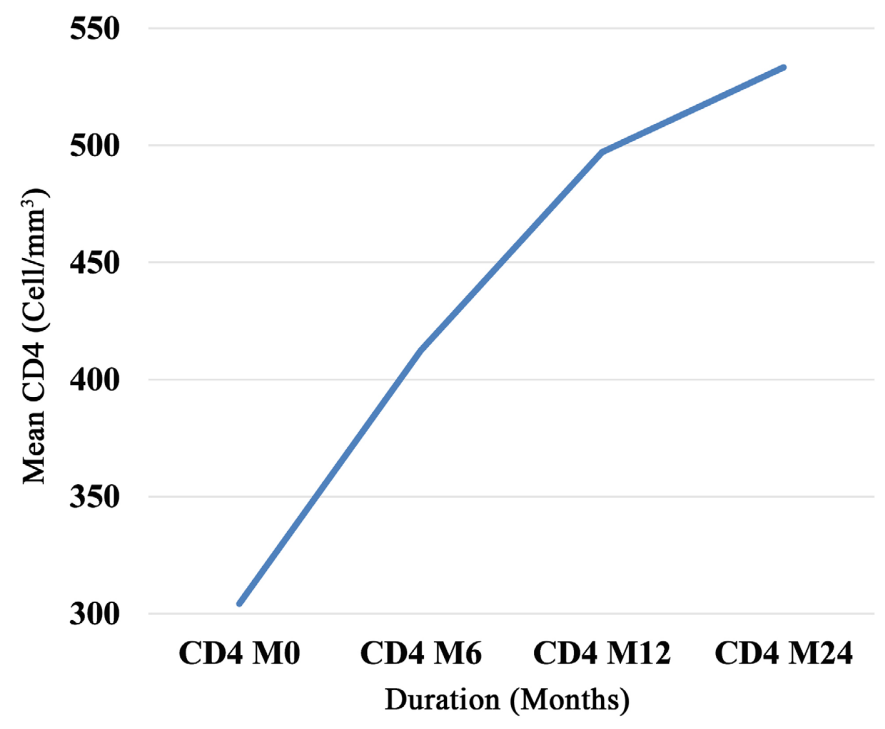

Figure 2. Changes in CD4 count as a function of follow-up time. Legend: TCD4 = TCD4 lymphocytes; $\mathrm{M} 0=$ month $0, \mathrm{M} 6=6$ months, $\mathrm{M} 12=12$ months, $\mathrm{M} 24=24$ months.

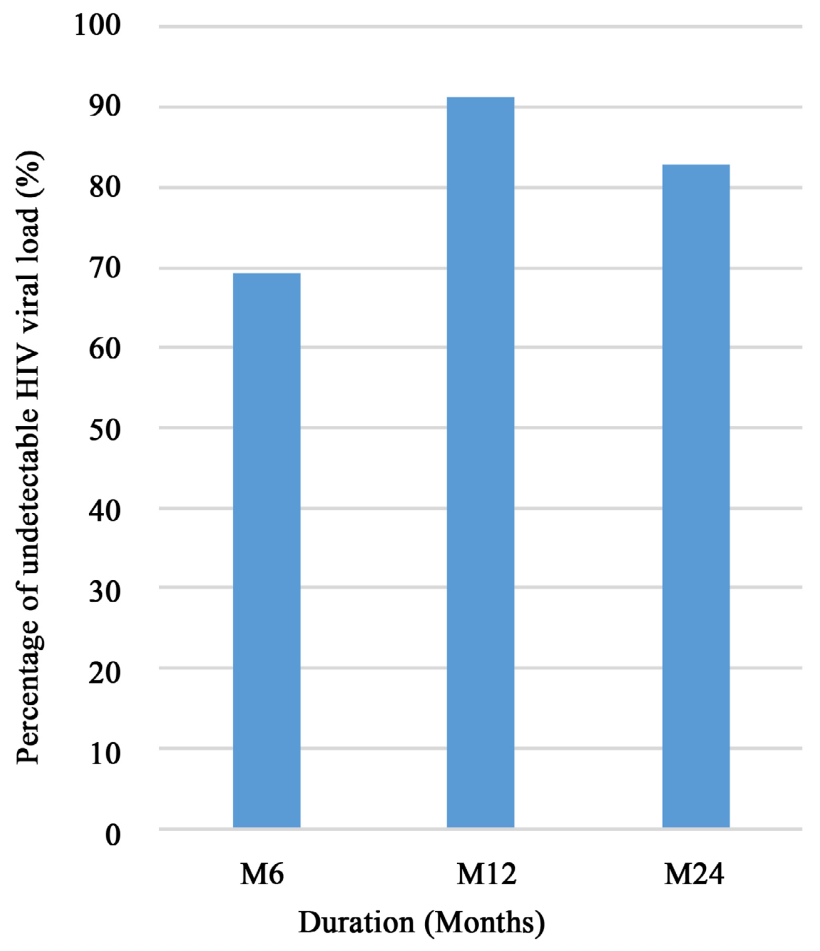

Figure 3. Percentage of undetectable HIV viral loads during follow-up. Legend: M6 = 6 months, M12 = 12 months, M24 = 24 months.

$11.6 \mathrm{~g} / \mathrm{dl} ; 127$ patients (40.32\%) were anemic of which only 01 had severe anemia. The mean creatinine clearance was $97.7 \pm 27.98 \mathrm{~mL} / \mathrm{min} ; 11.08 \%$ of the patients had a clearance below normal $(90 \mathrm{~mL} / \mathrm{min})$.

5) Hepatitis B and C serology 
Hepatitis B serology was performed in 141 patients $(37.2 \%$ of the study population); among them, thirty-four (34) or (24.11\%) were HBsAg positive. Among these 141 patients, only 26 and 21 patients tested respectively for anti-HBc and anti-HBsAg and the results were positive in 8 and 1 of them respectively. In addition, HBeAg was positive in 2 of 12 patients tested and viral DNA in 3 of 5 patients tested. Hepatitis C serology was performed in 78 patients $(20.58 \%$ of the study population); among them, 02 (2.26\%) were positive for anti-HCV Ac. Viral RNA was not tested in any of the patients. Table 5 shows the distribution of patients according to hepatitis $\mathrm{B}$ and $\mathrm{C}$ serology at treatment initiation.

6) $H I V, H B V$ and $H C V$ co-infection

From the Venn diagram, it appears that the probability of $\mathrm{HIV} / \mathrm{HBV}$ co-infection was high and estimated at $0.29 \%$ or $29.90 \%$, that of $\mathrm{HBV} / \mathrm{HCV}$ co-infection was low $(0.0093 \%$ or $0.93 \%)$ and that of HIV/HCV co-infection was zero $(0 \%)$. Also, the probability of triple HIV/HBV/HCV co-infection was low and $0.0093 \%$ or $0.93 \%$. Furthermore, the probability of being infected with HIV and/or HBV and/or HCV was null if the patient had arterial hypertension.

7) First-line treatment

In the study population, patients who started their antiretroviral treatment according to the 2 INTI +1 INNTI regimen were statistically higher ( $p$-value < $2.2 \mathrm{e}-16)$, i.e. a frequency of $73.35 \%$, with a predominance of the TDF-3TC-EFV protocol $(45.9 \%)$, followed by the 2INTI + 1INI (TDF-3TC-DTG) regimen, which accounted for 22.96\%. Among the $34 \mathrm{HBsAg}$ patients, 11 were followed in parallel by a gastrologist and $100 \%$ had TDF in their treatment regimen according to WHO recommendations. After initiation of treatment, $9.76 \%$ of the patients experienced treatment failure requiring a change in the treatment regimen. Table 6 shows the distribution of patients according to their first-line treatment regimen.

Table 5. Distribution by hepatitis B and C serology.

\begin{tabular}{ccc}
\hline Type & Modality & Positive/Tested \\
\hline HBsAg & $24.11 \%(34 / 141)$ \\
AcAntiHBs & $4.76 \%(1 / 21)$ \\
AgHBe & $16.67 \%(2 / 12)$ \\
\hline HBV & AcAntiHBe & $75 \%(3 / 4)$ \\
& AcAntiHBc & $30.77 \%(8 / 26)$ \\
& viral DNA & $60 \%(3 / 5)$ \\
& AcAntiHCV & $2.26 \%(2 / 78)$ \\
\hline HCV & & None \\
\hline
\end{tabular}


Table 6. Distribution of patients according to their treatment regimen at initiation of treatment.

\begin{tabular}{ccc}
\hline Treatment regimen & Frequency (\%) & P-value \\
\hline 2INTI + 1INNTI & $278 / 379(73.35)$ & \\
2INTI + 1INI & $87 / 379(22.96)$ & $<2.2 \mathrm{e}-16$ \\
2INTI + 1IP/r & $14 / 379(3.69)$ & \\
Total & $379 / 379(100)$ & \\
\hline
\end{tabular}

$\mathrm{p}<0.05$.

\section{8) Patient outcomes}

Retention in the active file of the study population was $75.2 \%$. The mortality rate was $3.69 \%$. The following table shows the outcome of the patients included in the study. With a p-value of 2.2e-16 indicating significant differences (Table 7).

\section{Discussion}

The present study included 280 women or $73.88 \%$ of the total population. This gives an M/F sex and West Africa. Thus, in Benin, Amidou et al. (2018) found $65.1 \%$ the same female trend in their study [19]. This female predominance found in the study populations is a reflection of the feminization of HIV infection in Africa where 58\% of HIV positive women are found out of the total of sub-Saharan Africa [17]. This feminization of HIV infection in Burkina Faso could be explained by a much higher use of health services by women. This feminization of HIV infection in Burkina Faso could be explained by a much greater use of health services by women. Moreover, Burkina Faso has emphasized PMTCT, which allows many pregnant women to be screened. Also according to the national committee for the fight against HIV, the general population of Burkina Faso is mostly female (51.7\%) [18]. In addition, many factors favor women's vulnerability to HIV infection, compared to men who are protected by circumcision, anatomical factors; physiological (the vagina due to its large surface and fragility facilitates the penetration of the virus, as well as the frequency of STIs); socio-cultural factors (sexual activity tends to be early in women and generally with older partners) [17]. This study revealed that the average age of patients was $40.14 \pm 11.84$ years with extremes of 18 and 81 years. The most represented age groups were 35 - 45 years with a frequency of $31.66 \%$. HIV affects the most active portion of the population [18] [19] [20] [21]. Indeed, HIV+ patients' age was from 25 to 52 years with an average of $32.0 \pm 7.8$ in this study in Burkina Faso [22]. Unemployed patients were the most represented $31.66 \%$ and housewives constituted the major $(25.65 \%)$. The majority of our study population (96.06\%), resided in urban areas and only (3.94\%) resided in rural areas. Moreover, a large proportion of them (93.93\%) were from the city of Ouagadougou where the study was conducted. These results probably reflect the policy of decentralization of care for people living with HIV promoted by Burkina Faso. 
Table 7. Patient outcomes.

\begin{tabular}{cccc}
\hline Patient outcome & Workforce & Frequency $(\%)$ & P-value \\
\hline Deceased & 14 & 3.69 & \\
Active file & 285 & 75.2 & $<2.2 \mathrm{e}-16$ \\
& & & \\
Lost and Found & 66 & 17.41 & \\
Transferred & 14 & 3.69 & \\
Total & 379 & 100 & \\
$\mathrm{p}<0.05$. & &
\end{tabular}

Patients in couples made up $56.21 \%$ of the population, $46.71 \%$ of whom were married. These results are similar to those of other authors in Africa [19] [20] [22] [23]. The majority (35.09\%) were uneducated and only $11.35 \%$ of the patients had attained tertiary education. These results could be explained by the fact that sub-Saharan Africa records one of the lowest school enrolment rates in the world with large gender disparities [24]. Burkina Faso in particular noted in 2020, a gross enrolment rate at $64.9 \%$ [25]. The percentage of notification to sexual partners in our study was only $32 \%$. These data corroborate those of the Keneya project which indicate that by the end of August 2015, 32\% of 4106 HIV PLWHA who received care and support services in the health districts of Bouake North-West and Korhogo had effectively notified their HIV status to their partners [26]. Thus, notification of HIV status and testing of sexual partners of HIV-PVs continues to be a challenge due to a number of apprehensions faced by HIV-positive people, including stigma, domestic violence, or fear of the relationship ending.

The prevalence of hypertension was $2.37 \%$. Arterial hypertension among HIV PLWHA in the world [27] and in Bobo Dioulasso [28] was higher respectively $23.6 \%$ and $39.8 \%$. This difference could be explained by the lack of data on the blood pressure figures of the patients included in our study. In the present study, clinical suspicion was the most frequent screening circumstance with $51.71 \%$ of cases. Pitroipa et al. (2013) and Sanon et al. (2014) in Bobo Dioulasso reported screening percentages following clinical suspicion of $68.2 \%$ and $70.5 \%$ [20] [21]. Some authors reported higher rates of discovery of the disease after clinical suspicion; in DRC 78.1\% [29] and 96.3\% in Benin [30]. On the other hand, Fonquernie et al. (2006), Kilaru (2004), Adamou et al. (2010) reported much lower rates respectively $23 \%, 57.6 \%$ and $41.7 \%$ [31] [32] [33]. This high rate in our study could be explained by an early detection policy that is still insufficiently encouraging, illiteracy, and a strong fear of stigmatization and discrimination on the part of our populations [34] [35]. WHO III clinical stage was statistically higher $51.45 \%$ of cases ( $\mathrm{p}$-value $<2.2 \mathrm{e}-16$ ). Elsewhere, in resource-limited countries, the majority of patients are recruited at stages 3 or 4 in Burkina Faso [20] [21] [30]. The low attendance of health centers by the population and the 
non-systematic screening for HIV infection could explain these results. The average BMI in our study population was $23.14 \pm 5.7 \mathrm{~kg} / \mathrm{m}^{2}$ and $50.5 \%$ had a normal BMI. Ilboudo (2013) reported that 53.2\%) of patients had normal or above normal BMI and Sanon et al. (2014) $18.5 \mathrm{~kg} / \mathrm{m}^{2}$ (64\%) [21] [36]. Clinical events after ART initiation were dominated by diarrhea and herpes zoster with $28 \%$ and $16 \%$ respectively. Clinical events were also dominated by diarrhea (29\%) [20]. The weak immune system favors these small infections. Moreover, HIV-1 was the largely predominant serotype and concerned 345 patients or $91.03 \%$. Sanon et al. (2014) and Ilboudo (2013) found respectively and 94.7\% and 93\% of predominance to HIV1 [21] [36]. This distribution of serotypes is perfectly characteristic of our country [18] and in the sub-region, in Côte d'Ivoire, Mali, Ghana where a predominance of HIV-1 was noted respectively $97 \%, 88.4 \%$, and 99.3\% [37] [38]. At treatment initiation the mean CD4 T cell count was $304.17 \pm$ $242.06 \mathrm{cells} / \mu \mathrm{L}$ with extremes ranging from 1 to 1286 . The majority of patients (42.59\%) had a CD4 count below 200 cells/ $\mu \mathrm{L}$. These results are comparable to other authors in Africa [30]. This could be explained by late detection and late [23] [30]. And or often inappropriate, management; some patients with HIV infection are managed by traditional medicine or by prayer houses. Poverty, ignorance but also stigmatization of the patients would delay a quick treatment noted similar results, with $60.4 \%$ of patients having less than 200 cells/ $\mu \mathrm{L}$. In contrast, in developed countries, in France, the median number was 374 cells $/ \mu \mathrm{L}$ and slightly more than half of patients had more than 350 cells/ $\mu \mathrm{L}$ [31]. In Bordeaux, Costa reported that $73.4 \%$ of patients had a CD4 count of over 350 cells $/ \mu \mathrm{L}$ ) [39]. The same finding in Nigeria where the median CD4 count was 478 cells/ $\mu \mathrm{L}$ [40]. As access to care is easier in developed countries, this could explain why patients are detected at an earlier stage of the disease.

The viral load at therapeutic initiation was documented in only 62 patients, $16.35 \%$ of our population, and $70.97 \%$ of patients had a detectable viral load (greater than 1000 copies $/ \mathrm{mL}$ ). On the other hand, Costa in Bordeaux noted a prevalence of undetectable viral load of $81.2 \%$ (less than 1000 copies $/ \mathrm{mL}$ ). This difference could be explained by the precariousness of the health services in Africa but also by the insufficiency of the available data on the viral load (VC) at the therapeutic initiation. Indeed, in Africa, the accessibility of the initial viral load is difficult because of its rarity. Also, many patients who are not compliant enough do not carry out the prescribed tests.

In relation to viral hepatitis serology, $24.11 \%$ or 34 patients were HBsAg positive. This result certainly does not reflect the real prevalence of co-infection in our population, as only 141 patients out of 379 were tested. Given the high costs, only patients with symptoms suggestive of hepatitis are tested. It is therefore more than necessary to facilitate the access to the realization of these examinations to this layer of the population in order to improve their general management.

Our results were superior to those reported by some African researchers. In- 
deed, Amidou et al. (2018), Sanon et al. (2014) and Ouedraogo et al. (2016), in Burkina, in Benin, had found prevalences of $13.9 \%, 17.3 \%$, and $12.86 \%$, in their study population [19] [21] [23]. Attia (2012) in Cote d'Ivoire, Sagoe (2012) in Ghana also found lower prevalences than ours which were $13.4 \%$ and $13 \%$ respectively in ARV treatment naive patients [37] [38]. Significantly lower prevalences were also reported, $7.9 \%$ and 3.8\% [40] [41]. This could be explained, on the one hand, by the selection criteria of the study population. Indeed, our study was on ARV treatment naïve patients; whereas some studies [23] [40] [41], concerned populations composed essentially of patients under treatment. The presence of ARV treatment can lead to a possible HBsAg seroconversion. On the other hand, it is also necessary to take into account the fact that Burkina Faso is part of the high prevalence areas of HBV infection $(>8 \%)$. In addition, the prevalence of $24.11 \%$ of viral hepatitis B in our cohort of HIV infected patients was higher than that of the general population of our country [42]. This could be explained by the similarity of HIV and HBV transmission routes. This is why since 2015 the WHO has advocated for the routine inclusion of Tenofovir in combination therapies for the first-line treatment of HIV infections. Indeed, Tenofovir is effective on both HIV and HBV. In our study, this recommendation had been implemented in all $\mathrm{HIV} / \mathrm{HBV}$ co-infected (100\%) against only $44.44 \%$ in the study conducted by Ouedraogo et al. (2016) [23]. In this population, 26 and 21 patients achieved Anti $\mathrm{HBc} A \mathrm{c}$ and Anti HBs Ac respectively. Among the latter, 8 were positive for Anti $\mathrm{HBc}$ (immunized patients) and 1 for Anti HBs (cured patient) that is respectively prevalences of $30.76 \%$ and $4.76 \%$. These results are higher than those found by Farid et al. (2019) [41] in Belgium who noted prevalences of Anti $\mathrm{HBc}$ and $\mathrm{HBeAg}$ of $10.5 \%$ and $1.3 \%$. This could be explained by the size of the samples tested. Indeed, many prescribers in our context limit themselves to prescribing HBsAg for hepatitis B screening, the other parameters ( $\mathrm{HBeAg}$, Anti $\mathrm{HBc}$, Anti $\mathrm{HBsAg}$ ) being very rarely prescribed. As for the prevalence of hepatitis C, 02 patients out of 78 (2.26\%) were positive for HCV antibody. Our results were similar to those found by Ouédraogo et al. (2016) [23] in his study on HIV/HBV and HIV/HCV co-infections in Ouagadougou (2.14\%). However, this prevalence is significantly lower than that of the general population of Burkina Faso. Koné (2016) [22] in Mali and Forbi et al. (2007) [40] in Nigeria noted prevalences of $6.5 \%$ and $11.1 \%$. In fact, the rate of hepatitis $\mathrm{C}$ serology in our context remains low, which underestimates the prevalences obtained. However, Rockstroh et al. (2005) [43] in Europe found in his study on the influence of Hepatitis $\mathrm{C}$ on the progression of HIV infection a much higher prevalence $(32.9 \%)$. This is due to the fact that injecting drug use, which is one of the main routes of $\mathrm{HCV}$ transmission, is still a growing phenomenon in Europe. Also, injecting drug users are much more likely to be screened for hepatitis $\mathrm{C}$ than the rest of the population. The probability of $\mathrm{HIV} / \mathrm{HBV}$ co-infection was $0.29 \%$ or $29.9 \%$, comparable to $37.18 \%$ probability found by Amona, et al. (2018) [44] in Congo Brazzaville. The probability of HIV/HCV co-infection and 
$\mathrm{HIV} / \mathrm{HBV} / \mathrm{HCV}$ triple co-infection was $0 \%$ and $0.93 \%$ respectively. On the other hand, these probabilities were higher $(2.7 \%$ and $0.7 \%)$ in the study conducted by Tremeau-Bravard (2013) [45] in Nigeria. These low rates found in our study would be explained by the low prevalence rate of hepatitis $C$ in our study; two (2) patients were positive for hepatitis $\mathrm{C}$; which made it difficult to relate the 03 infections.

In this study, we found weight gain in patients after initiation of ART. One of the goals of ART initiation is to improve the clinical status of patients, including suppression of opportunistic infections and weight gain. In adults, the factors influencing weight gain under ARV treatment include gender, CD4 T-cell count before initiation of treatment and treatment regimen. Furthermore, the number of clinical events decreased during follow-up. In fact, $89.97 \%$ of opportunistic infections found in our study were present during the first year of follow-up. These clinical results which are comparable to those of Pitroipa et al., (2013) [20] and Sanon et al. (2014) [21] reflect a good immune restoration. We observed an improvement of the immune and virological status after the initiation of the treatment with values of $\mathrm{CD} 4 \mathrm{~T}$ lymphocytes and $\mathrm{CV}$ progressive according to the duration of exposure to the treatment. In fact, one of the objectives of the treatment is the restoration of the immune and virological status of the patients. Moreover, the mean CD4 rate and the mean CV at M12 and M24 found in our study were significantly higher than those found by Pitroipa et al. (2013) [20]; Ilboudo, (2013) [36]. This could be explained by the implementation since the end of 2015 of the new recommendations for the management of HIV infected patients. Indeed, the success of treatment depends on early introduction. Numerous studies have shown that early initiation of treatment considerably reduces HIV-related morbidity and mortality as well as transmission of the virus [17] [46]. Thus, the aim of the new recommendations is to move from a therapeutic notion to a preventive one by using treatment as a means of controlling the epidemic at a time when other prevention systems are coming up against certain limitations, notably because sexual attitudes are very difficult to change [46]. On the other hand, $12.14 \%$ and $11.08 \%$ of patients had immunological and virological failure respectively under treatment. This can be explained by the insufficient follow-up of patients on ART. Indeed, therapeutic success also requires rigorous biological monitoring. However, this is lacking in our context due to insufficient laboratory equipment on the one hand, and on the other hand by the failure of patients to keep follow-up appointments, a phenomenon that has become more pronounced with the advent of COVID 19.

Indeed, many facilities that used to perform viral load tests have been requisitioned for the management of COVID 19 cases. Despite of stringent control measures, COVID-19 continues to circulate worldwide, severely disrupted the health care system and halted socioeconomic activities [47]. Also, a virological success (undetectable viral load) was reported in $91.25 \%$ of patients who started treatment after 6 months of follow-up against $82.76 \%$ after 12 months. This is 
due to the abandonment of health services and treatment by some patients after having noticed some improvement in their health status. Measures should therefore be taken to better equip the testing laboratories and also to sensitize HIV PLWHA on the importance of adhering to their follow-up schedule. In addition, patients with alanine amine transferase levels above normal represented $2.97 \%$ of the study population. The mean was $28.58 \pm 28.83$ IU with extremes of 0 and 355.7. Elevated transaminases could be associated with co-infection with hepatitis viruses, use of traditional drugs or alcohol consumption. The mean creatinine clearance was $97.7 \pm 27.98 \mathrm{~mL} / \mathrm{min} ; 11.08 \%$ of patients had a clearance below normal $(90 \mathrm{~mL} / \mathrm{min})$. Alterations in renal function are common in HIV-infected subjects; this would be associated with black race, older age, presence of hypertension or diabetes and advanced state of immunosuppression [48] [49]. A large proportion of patients were anemic (40.32\%). Other studies report the high frequency of anemia in HIV infected patients. Pitroipa et al. (2013) noted a frequency of anemia of $47 \%$ [20], ranging up to $85.2 \%$ [21]. Generally, anemia is multifactorial in cause and is reported to be related to inflammatory syndrome, immunosuppressed status, viral and bacterial comorbidities, black race and female sex among others [50]. In the study population, patients who started their antiretroviral treatment according to the 2INTI + 1INNTI regimen were statistically higher ( $\mathrm{p}$-value $<2.2 \mathrm{e}-16$ ), i.e. a frequency of $73.35 \%$, with a predominance of the TDF-3TC-EFV protocol (45.9\%). These results are in perfect correlation with the literature of the last few years [6] [8]. Many countries have in fact adopted the WHO recommendations, which indicate the 2INTI + 1INNTI protocol as the first-line treatment for HIV-1 positive patients. In addition, the TDF-FTC-EFV combination, due to its ease of use and greater availability in our countries, has been indicated as first-line therapy since 2013 by the WHO in the absence of contraindications to one of the molecules. However, the use of this regimen has been declining significantly. Indeed, Maud (2012) in Ouagadougou and Pitroipa et al. (2013) in Bobo Dioulasso noted a frequency of use of the 2INTI + 1INNTI protocol of $98 \%$ and $98.3 \%$ respectively [46] [20]. This regression is attributable to the appearance in 2018 of a new highly effective molecule: Dolutegravir (INI) thus increasing the frequency of use of the 2INTI+ 1INI regimen (TDF-3TC-DTG) which had already been implemented in more than a hundred low- and middle-income countries [8] and which represented $22.96 \%$ of the regimens used in our study. Overall mortality in our study population during 5 years of follow-up was 3.6\%; lower than Pitroipa et al. (2013) (11.8\%) and Ilboudo (2013) (9.2\%) [20] [36]. This result certainly does not reflect the reality because there is a gap in the notification of deaths. Indeed, the service concerned by this study is not an inpatient unit, many patients die in other health centers. As a result, these patients are generally classified as lost to follow-up. However, the improvement in patient management with the new WHO recommendations could also explain this low mortality rate. Indeed, nationally the number of HIV related deaths has decreased from 3800 in 2015 to 3000 in 2019 [18]. 
Moreover, the frequency of lost to follow-up in our study was $17.41 \%$. This result is higher than that found by Pitroipa et al. (2013) (11.1\%) [20] and much higher than that of Ilboudo, (2013) (2.2\%) [36]. Among these 17.41\%, about 7\% were lost to view during the years 2020-2021. This can be explained on the one hand by the failure to notify cases of death in the follow-up service which are attached to the lost to sight but also and especially by the epidemic context in COVID 19. Indeed, as collateral victims of this pandemic, people living with HIV (PLHIV) have suffered from the allocation of resources (human, material and financial), initially intended for their care, to the care of coronavirus patients. It would thus be advisable to establish strategies in order to minimize at most the repercussions of the fight against COVID 19 on the care of the HIV PLWHA at the risk of moving further away from the objectives fixed at the horizon 2030 (95-95-95), in order to end the AIDS epidemic.

\section{Conclusion}

This study showed that the patients were mostly young, uneducated women. HIV1 was the predominant serotype. The pathologies frequently reported at the first consultation were diarrhoea and herpes zoster, and nearly $43 \%$ of the patients had less than $200 \mathrm{CD} 4 / \mu \mathrm{L}$, reflecting late screening of the patients and consequently the initiation of late antiretroviral treatment, which could compromise the subsequent prognosis of the infection in these newly treated patients. The clinical and biological evolution was relatively good in the patients after the initiation of treatment. Indeed, weight gain and immune restoration were progressive in the majority. Also, the clinical events decreased during the follow-up; the CD4 gain during the follow-up was regular and the viral load after 06 months of follow-up became undetectable in nearly $92 \%$ of the patients. This shows the crucial importance of putting patients who test positive on treatment. HIV-HBV co-infection was $24.11 \%$ and HIV-HCV co-infection was $2.26 \%$ above the national prevalence in the general population. Thus, we can affirm that hepatitis $\mathrm{B}$ and/or $\mathrm{C}$ is co-infections that increasingly affect people living with HIV. In addition, the number of people lost to follow-up has increased considerably in recent years due to the advent of COVID 19.

\section{Recommendations}

The results of this study show that it is undeniable that emphasis should be placed on raising awareness of the culture of early detection among the population in order to prevent contamination and improve progress on ART, but also to develop effective strategies for combating HIV in times of other epidemics and/or pandemics. It would also be appropriate to systematically search for HBV and HCV infection when HIV infection is discovered.

\section{Acknowledgements}

Authors are grateful to Hospital Saint Camille of Ouagadougou for the working 
facilities and technical assistance. Thank to M. Ambroise Koanda for Statistical analysis.

\section{Author Contributions}

Study concept and design: TMZ, IPD, and WWEKS. Sample collection and processing: WWEKS and ES. Statistical analysis and interpretation of data: WWEKS, IPD, TMZ. Drafting of the manuscript: WWEKS, IPD and TMZ. Critical revision of the manuscript for important intellectual content: YEH, LT, DO, WFD, CMN, MB, PO, MS, DSK, YT and JS. Study supervision: TMZ, IPD and JS.

\section{Conflicts of Interest}

The authors declare no competing interests.

\section{References}

[1] Koziel, M.J. and Peters, M.G. (2007) Viral Hepatitis in HIV Infection. New England Journal of Medicine, 356, 1445-1454. https://www.ncbi.nlm.nih.gov/pmc/articles/PMC4144044/pdf/nihms615418.pdf

[2] Thio, C.L. (2009) Hepatitis B and Human Immunodeficiency Virus Coinfection. Hepatology, 49, S138-S145. https://doi.org/10.1002/hep.22883 https://aasldpubs.onlinelibrary.wiley.com/doi/epdf/10.1002/hep.22883

[3] Nikolopoulos, G.K., Paraskevis, D., Hatzitheodorou, E., Moschidis, Z., Sypsa, V., Zavitsanos, X., Kalapothaki, V. and Hatzakis, A. (2009) Impact of Hepatitis B Virus Infection on the Progression of AIDS and Mortality in HIV-Infected Individuals: A Cohort Study and Meta-Analysis. Clinical Infectious Diseases, 48, 1763-1771. https://pubmed.ncbi.nlm.nih.gov/19435436/ https://doi.org/10.1086/599110

[4] Lacombe, K., Boyd, A., Gozlan, J., Lavocat, F., Girard, P.M. and Zoulim, F. (2010) Drug-Resistant and Immune-Escape HBV Mutants in HIV-Infected Hosts. Antiviral Therapy, 15, 493-497. https://pubmed.ncbi.nlm.nih.gov/20516570/ https://doi.org/10.3851/IMP1495

[5] Aman, W., Mousa, S., Shiha, G. and Mousa, S.A. (2012) Current Status and Future Directions in the Management of Chronic Hepatitis C. Virology Journal, 9, Article No. 57. https://virologyj.biomedcentral.com/articles/10.1186/1743-422X-9-57 https://doi.org/10.1186/1743-422X-9-57

[6] Yuen, M.F. and Lai, C.L. (2011) Treatment of Chronic Hepatitis B: Evolution over Two Decades. Journal of Gastroenterology and Hepatology, 26, 138-143. https://pubmed.ncbi.nlm.nih.gov/21199525/ https://doi.org/10.1111/j.1440-1746.2010.06545.x

[7] Tan, Y., Wei, Q.H., Chen, L.J., Chan, P.C., Lai, W.S., He, M.L., Kung, H.F. and Lee, S.S. (2008) Molecular Epidemiology of HCV Monoinfection and HIV/HCV Coinfection in Injection Drug Users in Liuzhou, Southern China. PLoS ONE, 3, e3608. https://journals.plos.org/plosone/article?id=10.1371/journal.pone.0003608 https://doi.org/10.1371/journal.pone.0003608

[8] Maud, L., Shevanthi, N. and Mark, T. (2013) Viral Hepatitis in Resource-Limited Countries and Access to Antiviral Therapies: Current and Future Challenges. $\mathrm{Fu}$ ture Virology, 8, 371-380. 
https://www.ncbi.nlm.nih.gov/pmc/articles/PMC3646239/pdf/emss-52933.pdf

[9] Schweitzer, A., Horn, J., Mikolajczyk, R.T., Krause, G. and Ott, J.J. (2015) Estimations of Worldwide Prevalence of Chronic Hepatitis B Virus Infection: A Systematic Review of Data Published between 1965 and 2013. The Lancet, 386, 1546-1555. https://doi.org/10.1016/S0140-6736(15)61412-X

[10] Olayinka, A.T., Oyemakinde A., Balogun, M.S., Ajudua, A., Nguku, P., Aderinola, M., Egwuenu-Oladejo, A., Ajisegiri, S.W., Sha'aibu, S., Musa, B.O.P., Gidado, S. and Nasidi, A. (2016) Seroprevalence of Hepatitis B Infection in Nigeria: A National Survey. The American Society of Tropical Medicine and Hygiene, 95, 902-907. https://doi.org/10.4269/ajtmh.15-0874

[11] Kouassi-Mbengue, A., Ouattara, A., Allah-Kouadio, E., Sevede, D., Doumbia, M. and Dosso, M. (2016) Hepatitis B virus in Cote d'Ivoire (West Africa). Journal of Liver, 5, 2.

https://www.walshmedicalmedia.com/conference-abstracts-files/2167-0889.C1.005 00 9.pdf https://www.longdom.org/conference-abstracts-files/2167-0889.C1.005 009.pdf

[12] Ilboudo, D., Sawadogo, A. and Simpore, J. (2002) Mother-to-Child Transmission of Hepatitis B Virus in Ouagadougou (Burkina Faso). Medecine Tropicale, 62, 99-101.

[13] Meda, M. Tuaillon, E., Kania, D., Tiendrebeogo, A., Pisoni, A., Zida, S., Bollore, K., Medah, I., Laureillard, D., Moles, JP., Nagot, N., Nebie, K.Y., Van de Perre, P. and Dujols, P. (2018) Hepatitis B and C Virus Seroprevalence, Burkina Faso: A Cross-Sectional Study. Bulletin of the World Health Organization, 96, 750-759. https://doi.org/10.2471/BLT.18.208603

[14] Périères, L., Diallo, A., Marcellin, F., Nishimwe, M.L., Ba, E.L., Coste, M., Lo, G., Halfon, P., Kane, C.T., Maradan, G., Carrieri, P., Diouf, A., Shimakawa, Y., Sokhna, C. and Boyer, S. (2021) Hepatitis B in Senegal: A Successful Infant Vaccination Program but Urgent Need to Scale up Screening and Treatment (ANRS 12356 AmBASS Survey). Hepatology Communications. https://doi.org/10.1002/hep4.1879 https://aasldpubs.onlinelibrary.wiley.com/doi/epdf/10.1002/hep4.1879

[15] Sonderup, M.W., Afihene, M., Ally, R., Apica, B., Awuku, Y., Cunha, L., Dusheiko, G., Gogela, N., Marie-Lohouès-Kouacou, J., Lam, P., Lesi, O., Mbaye, P.S., Musau, E.M.B., Ojo, O., Rwegasha, J., Scholz, B., Shewaye, A.B., Tzeuton, C., Kassianides, C. and Spearman, C.W. (2017) Hepatitis C in Sub-Saharan Africa: The Current Status and Recommendations for Achieving Elimination by 2030. The Lancet Gastroenterology and Hepatology, 2, 910-919.

https://doi.org/10.1016/S2468-1253(17)30249-2

[16] Simpore, J., Ilboudo, D., Samandoulougou, A., Guardo, P., Castronovo, P. and Musumeci, S. (2005) HCV and HIV Co-Infection in Pregnant Women Attending St. Camille Medical Centre in Ouagadougou (Burkina Faso). Journal of Medical Virology, 75, 209-212. https://doi.org/10.1002/jmv.20258

[17] UNAIDS (2020) Global AIDS Monitoring Report 2021: Indicators for Monitoring the Political Declaration on Ending AIDS Adopted by the United Nations General Assembly in 2016. 208 p.

https://www.unaids.org/sites/default/files/media asset/global-aids-monitoring en.p df

[18] National Council for the Fight against AIDS and STIs (2019) Progress Report on the AIDS Response in Burkina Faso. Global Aids Monitoring (GAM), 35 p.

https://www.unaids.org/sites/default/files/country/documents/BFA 2019 countryre port.pdf 
[19] Amidou, S.A., Dovonou, C.A., Houehanou, C., Kpangon, A.A., Ahanhanzo-Glele, R. Kpangon, J.H., Alassan, K.S, Angelo, A.C., Tchaou, B., Salifou, K., Adoukonou, T., Zannou, D.J. and Houinato, D.S. (2018) Prevalence of Chronic Hepatitis B According to HIV Status in Parakou, Benin. Pan African Medical Journal, 30, Article No. 180.

[20] Pitroipa, E.M.M. (2013) Early Initiation of Antiretroviral Therapy According to WHO 2013 Recommendations: Typical Profile and Prognosis of Patients at the Day Hospital of CHUSS of Bobo-Dioulasso. Ph.D. Thesis, University of Bobo-Dioulasso, Bobo-Dioulasso, $98 \mathrm{p}$.

[21] Sanon, L. (2014) Socio-Demographic, Clinica and Biological Profiles of HIV Infected Patients Newly Treated at the Hôpital De Jour de Bobo Dioulasso. Thèse de Doctorat, Institut Supérieur de Sciences de la Santé (IN.S.SA), Bobo-Dioulasso. http://bibliovirtuelle.u-naziboni.bf/biblio/opac css/docnume/inssa/medeine/

[22] Henry, S.R., Hien, Y.H., Sanou, S.G., Kima, A., Ilboudo, D.P., Kabre, E. and Traore, Y. (2021) Evolution of Biochemical, Hematological, Inflammatory and Immunological Markers among Person Living with HIV-1 on ART in Burkina Faso. Advances in Infectious Diseases, 11, 104-121. https://www.scirp.org/journal/aid https://www.scirp.org/journal/paperinformation.aspx?paperid $=108378$

[23] Ouedraogo, M.S., Bara/Tiendrebeogo, S., Tapsoba, P.G, Korsaga/Some, N. Ouedraogo, A.N., Tiendrebeogo, L., Yameogo, A., Barro/Traoré, F., Niamba, P. and Traoré, A. (2016) CO 13: HIV/Hepatitis B and C Co-Infection in People Living with HIV in an Associative Medical Care Structure in the City of Ouagadougou (Burkina Faso). Annales de Dermatologie et de Vénéréologie, 143, S25.

https://doi.org/10.1016/S0151-9638(16)30140-5

[24] Baten, J., de Haas, M., Kempter, E. and zu Selhausen, F.M. (2021) Educational Gender Inequality in Sub-Saharan Africa: A Long-Term Perspective. Population and Development Review, 47, 813-849. https://doi.org/10.1111/padr.12430 https://onlinelibrary.wiley.com/doi/epdf/10.1111/padr.12430

[25] UNESCO (2020) School Enrollment, Primary (\% Gross)—Burkina Faso. https://data.worldbank.org/indicator/SE.PRM.ENRR?locations $=\mathrm{BF}$

[26] Glaser, E. (2017) HIV Status Disclosure and Testing among Sexual Partners of People Living with HIV: Lessons Learned from Project Keneya. Project Keneya Brief.

https://www.pedaids.org/wp-content/uploads/2017/11/DisclosureBrief Apr24-page s.pdf

[27] Nansseu, J.R., Ndoadoumgue, A.L., Tochie, J.N., Nyaga, U.F., Nkeck, J.R., Foka, A.J., Kazeh, A.D., Noubiap, J.J. and Bigna, J.J. (2020) High Blood Pressure: A Heavy Burden for People Living with HIV Worldwide.

[28] Hema, A, Poda, A, Tougouma, J-B, Meda, C., Kabore, F., Zoungrana, J., Kamoule, E., Soré, I., Bado, G., Ouedraogo, A.S., Sawadogo, A.B. and Millogo, A. (2021) Sur-Risk of Diabetes Mellitus and Hypertension among HIV-Infected Persons Followed at the Day Hospital of CHU Sourou Sanou, Bobo-Dioulasso, Burkina Faso, 2018. Revue d' Epidémiologie et de Santé Publique, 69, 72-77.

https://doi.org/10.1016/j.respe.2020.12.001

[29] Kautako-Kiambi, M., Aloni-Ntetani, M., Pululu, P., Luyinduladio, L., Ezinga-Atshitsha, F., Lema-Landu, P. and Elika-Bothale, M. (2013) Socio-Demographic, Biological and Clinical Profile of Patients Living with HIV during Screening in a Voluntary Counselling and Screening Centre in a Rural Area of Mbanza-Ngungu, Democratic Republic of Congo, in 2006-2011. Bulletin de la Société de Pathologie Exotique, 106, 180-183. https://doi.org/10.1007/s13149-013-0297-6 
[30] Zannou, D.M., Kindé-Gazard, D., Vigan, J., Adè, G., Sèhonou, J.J., Atadokpèdé, F., Azondékon, A., Gbèdo, C., Anagonou, S.Y. and Houngbé, F. (2004) Clinical and Immunological Profile of HIV Infected Patients in Cotonou, Benin. Médecine et Maladies Infectieuses, 34, 225-228.

[31] Fonquernie, L., Dray-Spira, R., Bamogo, E., Lert, F. and Girard, P.M. (2006) Characteristic of Newly Managed HIV-Infected Patients: Hospital Saint Antoine, Paris 2002-2003. Médecine et Maladies Infectieuses, 36, 270-279.

[32] Kilaru, K.R., Kumar, A. and Sippy, N. (2004) CD4 Cell Counts in Adults with Newly Diagnosed HIV Infection in Barbados. Revista Panamericana de Salud Publica, 16, 302-307.

[33] Adamou, B., Elharti, E., Oumzil, H., Addebbous, A., Amine, M, Zahlane, K, Soraa, N., Zougaghi, L., Haouach, K., Tassi, N., Aajly, L., Chabaa, L. and El Aouad, R. (2010) Clinical and Immunological Status of a Newly Diagnosed HIV Positive Population, in Marrakech, Morocco. African Health Sciences, 10, 325-331.

[34] Millogo, A., Sawadogo, A.B., Sawadogo, A.P. and Lankoandé, D. (2002) Peripheral Neuropathies Revealing HIV Infection at the Hospital Center of Bobo-Dioulasso, Burkina Faso. Bulletin de la Société de Pathologie Exotique, 95, 27-30.

[35] Allain, J.P. and Candotti, D. (2009) Diagnostic Algorithm for HBV Safe Transfusion. Blood Transfusion, 7, 174-182.

[36] Ilboudo, B.M.P. (2013) Epidemiological, Clinical, Paraclinical and Evolutionary Aspects of Viral Hepatitis B in HIV-Infected Patients at the Bobo Dioulasso Day Hospital. Doctoral Dissertation, Institut Supérieur de Sciences de la Santé (IN.S.SA), Bobo-Dioulasso.

https://beep.ird.fr/collect/upb/index/assoc/INSSA-2013-ILB-ASP/INSSA-2013-ILBASP.pdf

[37] Attia, K.A., Eholié, S., Messou, E., Danel, C., Polneau, S., Chenal, H., Toni, T., Mbamy, M., Seyler, C., Wakasugi, N., N'dri-Yoman, T. and Anglaret, X. (2012) Prevalence and Virological Profiles of Hepatitis B Infection in Human Immunodeficiency Virus Patients. Word Journal of Hepatology, 4, 218-223.

https://doi.org/10.4254/wjh.v4.i7.218

[38] Sagoe, K.W.C., Agyei, A.A., Ziga, F., Lartey, M., Adiku, T.K., Seshi, M., Arens, M.Q. and Mingle, J.A.A. (2012) Prevalence and Impact of Hepatitis B and C Virus Co-Infections in Antiretroviral Treatment Naive Patients with HIV Infection at a Major Treatment Center in Ghana. Journal of Medical Virology, 84, 6-10. https://doi.org/10.1002/jmv.22262

[39] Costa, M., Rojas, T.R., Lacoste, D., Villes, V., Aumaitre, H., Protopopescu, C., Yaya, I., Wittkop, L., Krause, J., Salmon-Céron, D., Marcellin, F., Sogni, P. and Carrieri, M.P. (2019) Sleep Disturbances in HIV-HCV Coinfected Patients: Indications for Clinical Management in the HCV: Cure Era (ANRS CO13 HEPAVIH Cohort). European Journal of Gastroenterology and Hepatology, 31, 1508-1517.

https://pubmed.ncbi.nlm.nih.gov/31094856/

[40] Forbi, J.C., Gabadi, S., Alabi, R., Iperepolu, H.O., Pam, C.R., Entonu, P.E. and Agwale, S.M. (2007) The Role of Triple Infection with Hepatitis B Virus, Hepatitis C Virus, and Human Immunodeficiency Virus (HIV) Type-1 on CD4+ Lymphocyte Levels in the Highly HIV Infected Population of North-Central Nigeria. Memórias do Instituto Oswaldo Cruz, 102, 535-537. https://doi.org/10.1590/S0074-02762007005000025

[41] Farid, Y., Charlotte, M., Delforge, M. and De Wit, S. (2019) Epidemiology and Clinical Management of HIV-HBV Coinfected Patients in a Large AIDS Reference 
Center in Belgium. Acta Clinica Belgica, 746, 424-429. https://doi.org/10.1080/17843286.2018.1554292

[42] Coffie, P.A., Tchounga, B.K., Bado, G., Kabran, M., Mint, D.K., Wandeler, G., Gottlieb, G.S., Dabis, F., Serge, P., Eholie, S.P. and Ekouevi, D.K. (2017) Prevalence of Hepatitis B and Delta According to HIV-Type: A Multi-Country Cross-Sectional Survey in West Africa. BMC Infectious Diseases, 17, Article No. 466.

https://doi.org/10.1186/s12879-017-2568-5

[43] Rockstroh, J.K., Mocroft, A., Soriano, V., Tural, C., Losso, M.H., Horban, A., Kirk, O., Phillips, A., Ledergerber, B. and Lundgren, J. (2005) Influence of Hepatitis C Virus Infection on HIV-1 Disease Progression and Response to Highly Active Antriretroviral Therapy. The Journal of Infectious Diseases, 192, 992-1002. https://doi.org/10.1086/432762

[44] Amona, M., Aloumba, G.A., Kokolo, B., Loumouamou, M.L., Mbita, A.M., Doukaga, T.A., Amona, F.R., Moukassa, D. and Ibata, P. (2018) Influence de la co-infection VIH-VHB sur le taux de lymphocytes TCD4+ et sur la fonction hépa-

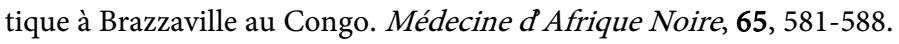

[45] Tremaeau-Bravard, A., Ogbukagu, I., Tiago, C. and Abubakar, J. (2012) Seroprevalence of Hepatitis B and C Infection among the HIV-Positive Population in Abuja, Nigeria. African Health Sciences, 12, 312-317. https://doi.org/10.4314/ahs.v12i3.10

[46] Clément, M. (2010) Comparative Study of Immune Restitution under First Line Antiretroviral Treatment between a Northern and a Southern Country. Human Medicine and Pathology, dumas-00626667.

https://dumas.ccsd.cnrs.fr/dumas-00626667v1

[47] Long, H., Zhao, J., Zeng, H.L., Lu, Q.B., Fang, L.Q., Wang, Q., Wu, Q.M. and Liu, W. (2021) Prolonged Viral Shedding of SARS-CoV-2 and Related Factors in Symptomatic COVID-19 Patients: A Prospective Study. BMC Infectious Diseases, 21, 1282. https://doi.org/10.1186/s12879-021-07002-w https://bmcinfectdis.biomedcentral.com/track/pdf/10.1186/s12879-021-07002-w.pdf

[48] Damaoal, R.A., McMahon, M., Thio, C.I.O., Bailey, C.M., Tirado-Rives, J., Obikhod, A., Detorio, M., Rapp, K.L., Siliciano, R.F., Schinazi, R.F. and Anderson, K.S. (2008) Pre-Steady-State Kinetic Studies Establish Entecavir 5'-Triphosphate as a Substrate for HIV-1 Reverse Transcriptase. Journal of Biological Chemistry, 283, 5452-5459. https://doi.org/10.1074/jbc.M707834200

[49] McMahon, M.A., Jilek, B.L., Brennan, T.P., Shen, L., Zhou, Y., Wind-Rotolo, M., Xing, S., Bhat, S., Hale, B., Hegarty, R., Chong, C.R., Liu, J.O., Siliciano, R.F. and Thio, C.L. (2007) The HBV Drug Entecavir-Effects on HIV-1 Replication and Resistance. The New England Journal of Medicine, 356, 2614-2621. https://doi.org/10.1056/NEJMoa067710

[50] Moses, A., Nelson, J. and Bagby, G.C. (1998) The Influence of Human Immunodeficiency Virus-1 on Hematopoiesis. Blood, 91, 1479-1495. https://doi.org/10.1182/blood.V91.5.1479 